\title{
Comparative analysis of oxygen consumption rates between cupped oyster spat of Crassostrea gigas of French, Japanese, Spanish and Taiwanese origins
}

\author{
Philippe Goulletquer ${ }^{(a *)}$, Maciej Wolowicz ${ }^{(b)}$, Adam Latala ${ }^{(b)}$, Philippe Geairon ${ }^{(a)}$, \\ Arnaud Huvet ${ }^{(c)}$, Pierre Boudry ${ }^{(c)}$ \\ (a) Shellfish Aquaculture Research Laboratory of Poitou-Charentes, Ifremer, B.P. 13317390 La Tremblade, France \\ (b) Laboratory of Estuarine Ecology, Institute of Oceanography, University of Gdañsk, Al.Marszalka J.Pilsudskiego 46, \\ 81-378 Gdynia, Poland \\ (c) Genetics and Pathology Research Laboratory, Ifremer, B.P. 133, 17390 La Tremblade, France
}

Received June 7, 1999; accepted July 30, 1999

\begin{abstract}
Respiration rates of various geographical strains of Crassostrea gigas were compared to assess the respiratory expenditure as a physiological indicator of catabolism (cost of maintenance). Parental oysters, sampled in France (Marennes-Oléron), Japan (Hiroshima), Taiwan (Tunkang) and Spain (Cadix), were differentiated by both their geographic origin and by mitochondrial DNA markers, allowing the distinction between the two closely related taxa Crassostrea gigas and Crassostrea angulata. After reproduction of these parental oysters, respiration rates of spat of each strain, reared under common controlled conditions, were individually estimated at $20^{\circ} \mathrm{C}$ by using a volumetric microrespirometer. Our results demonstrated that physiological variability existed among the Crassostrea gigas strains and is likely to be related to physiological differences between geographical regions and/or genetic adaptations. The French strain showed the highest rates $(0.71$ $\mu \mathrm{L} \cdot \mathrm{h}^{-1}$ ), while the Japanese, Taiwanese and the hybrid between Spanish and French strains consumed less, $0.53,0.43$ and $0.40 \mu \mathrm{L} \cdot \mathrm{h}^{-1}$, respectively. Our results confirmed the discrepancies previously suggested between Crassostrea gigas and Crassostrea angulata. Comprehensive physiological assessments should be carried out over a wide temperature range to confirm our results and to further evaluate growth potential. Appropriate decision making based on these studies will help future shellfish management in shellfish rearing areas such as the overstocked Marennes-Oléron Bay. (C) 1999 Ifremer/Cnrs/Inra/Ird/Cemagref/Éditions scientifiques et médicales Elsevier SAS
\end{abstract}

Respiration rates / metabolism / Crassostrea gigas / Crassostrea angulata / hybrids / oyster strains / NE Atlantic / Pacific Ocean

Résumé - Analyse comparée des taux de respiration de naissains de différentes souches d'huitres creuses japonaises Crassostrea gigas originaires de France, Espagne et Taiwan. Les taux de respiration de différentes souches géographiques de l'huître creuse japonaise Crassostrea gigas ont été comparés afin d'évaluer, en tant qu'indicateur physiologique, le coût énergétique de maintenance résultant du catabolisme (pertes énergétiques). Les géniteurs échantillonnés en France (Marennes-Oléron), au Japon (Hiroshima), à Taiwan (Tunkang) et en Espagne (Cadix) ont été différenciés à la fois par leur origine géographique et par l'utilisation de marqueurs ADN mitochondriaux, permettant ainsi la distinction entre deux taxa très proches Crassostrea gigas et Crassostrea angulata. Après reproduction de ces géniteurs, les taux de respiration du naissain de chaque souche, élevé dans des conditions contrôlées similaires, ont été mesurés individuellement à $20^{\circ} \mathrm{C}$ au moyen d'un microrespiromètre volumétrique. Nos résultats démontrent qu'il existe une variabilité physiologique entre les différentes souches, due probablement à une adaptation physiologique locale et/ou à des adaptations génétiques. Les huîtres de souche française ont montré les taux de respiration les plus élevés $\left(0,71 \mu \mathrm{L} \cdot \mathrm{h}^{-1}\right)$, comparés aux taux de consommation de $0,53,0,43$ and $0,40 \mu \mathrm{L} \cdot \mathrm{h}^{-1}$ respectivement pour les souches japonaise, taiwanaise et les hybrides entre la souche espagnole et française. Ces résultats confirment les différences déjà suggérées entre les souches Crassostrea angulata et Crassostrea gigas. Des évaluations complètes des fonctions physiologiques doivent être réalisées en fonction d'une gamme de température pour confirmer ces résultats et estimer le potentiel de croissance des différentes souches. Ces études doivent faciliter les futures décisions en matière d'aménagement des cultures marines dans les bassins de production français, en particulier dans des zones d'élevage surchargées comme le bassin de Marennes-Oléron. (C) 1999 Ifremer/Cnrs/Inra/Ird/Cemagref/Éditions scientifiques et médicales Elsevier SAS

Taux de respiration / métabolisme / Crassostrea gigas / Crassostrea angulata / hybrides / souches génétiques / Atlantique NE / océan Pacifique

* Corresponding author, e-mail: pgoullet@ifremer.fr 


\section{INTRODUCTION}

The Marennes-Oléron bay, France, is the highest yielding area for Pacific oyster Crassostrea gigas production in Europe. Between 40000 and 60000 metric tons are marketed annually. However, historical trends in French oyster production have shown large fluctuations over the century, the latest being the massive introduction of Crassostrea gigas during the 1970s to replace the ailing Crassostrea angulata affected by a viral disease $[14,18,20]$. This successful introduction led to an industry rebound and annual natural spatfall has occurred regularly over the subsequent 25 years, although it was poor for 2 years. In Marennes-Oléron Bay, overstocking became a major issue in 1985 when the relationship between the ecosystem carrying capacity and the overall stocking biomass was established [22], therefore demonstrating the limits of the bay carrying capacity. Unbalanced stocks of various size classes (mainly spat and 1 year old) induced decreasing growth rates and increased mortality rates. The overall impact has been a significant shift from an 18 month to a 3 year rearing cycle time to reach a marketable size [22]. To address this matter, and improve the economic yield, several issues were discussed. The obvious one was a systematic oyster stock decrease by new regulations and their enforcement (e.g. overall authorized stocking biomass is presently 6000 oysters bags or 72 metric tonnes per ha). However, discrepancies between optimized biological and economic yields should be taken into account to establish thresholds and regulations, therefore leading to new difficulties [1]. A simple new density regulation would be unlikely to be successful in limiting the stocking biomass, and a more specific economic analysis is required to assess the impact on the various shellfish farming trades (i.e. spat producers - growers and growers-marketers). Therefore, due to the overall complex organization, the shellfish farming industry was reluctant to push for such regulations. Instead new management practices were developed and enforced to reverse these trends: (1) limiting proliferation of trophic competitive species, including the exotic gastropod Crepidula fornicata by annual dredging $[24,25]$; (2) destruction of natural beds of Crassostrea gigas, classified as sanctuaries since its introduction; (3) increasing the cleaning and restructuring of the leasing grounds to limit wild oyster populations, estimated at 20000 metric tons [37].

Moreover, new rearing techniques are currently under evaluation using long lines and deep water oyster cultures located off shore which, combined with a decrease in intertidal leasing grounds, will limit and improve oyster stock spatial distribution (overall density decrease) $[17,19]$.

Besides the changes in overall shellfish management, oyster mortality rates, which have increased over 25 years, are also likely to have been affected by global environmental changes. A $1.5^{\circ} \mathrm{C}$ seawater temperature increase has been recorded in the bay of Marennes-Oléron since 1978 [39].

At a constant stocking biomass, this environmental change has induced increased physiological activity in oysters, and consequently a $4 \%$ decrease in the bay carrying capacity [39]. The oyster broodstock and spat which were introduced during the 1970s came from British Columbia (Canada) and Sendai-Miyagi (Japan) [33]. However, oysters in both cases originated from the latter as demonstrated by the lack of genetic differentiation between the French and the Miyagi populations [35]. In the Japanese environment, seawater temperatures peak at $25^{\circ} \mathrm{C}$ and salinity is below 33 in summer [32, 33]. Higher seawater temperatures are now regularly observed in summertime in the Marennes-Oléron bay. Moreover, mortality rates were correlated with Crassostrea gigas strains since oysters descended from Hiroshima and Matsushima stocks showed various mortality rates in similar environmental conditions [19, 28, 31].

Based on this information, scientific research programmes have focused on ecosystem modelling to assess the main constraints affecting the primary productivity and to improve knowledge on overall ecosystem functioning [24]. At the population level, genetic and ecophysiological studies have been carried out on Crassostrea gigas to assess strains characterized by optimized assimilation rates as well as by genetic characteristics $[6,7,10,13]$. A comprehensive research programme has been developed to study wild and cultured Crassostrea gigas populations on a worldwide basis to define the genetic structure and stock variability for these populations. In the near future, controlled introductions of shellfish populations may be of interest to the aquaculture industry by providing desirable traits and improved productivity through selective breeding. The main mid-term objective is the search for original genetic characteristics capable of improving the overall oyster culture yield in France, and in the long-term to specify a policy for a genetic management strategy for Crassostrea gigas [6, 7].

For the latter approach, a quarantine station at the Ifremer research hatchery (La Tremblade, France) has allowed experiments to be carried out on various Crassostrea sp. strains. The present study aims to assess respiration rate variability of several Crassostrea gigas strains to provide insights for the genetic management strategy. Respiration rate is considered as an appropriate physiological indicator of catabolism representing the overall bio-energetic status and respiratory expenditure (i.e. costs of maintenance) of the shellfish $[38,40]$. In examining the oxygen consumption rate, we supposed that oysters allocating a smaller proportion of their aerobic capacity to maintenance requirements would be able to allocate more energy to growth [21]. 
Table I. Sampling sites, status and characteristics of experimental batches of the various Crassostrea gigas strains (wild versus culture). Oyster strains: Cgf, Crassostrea gigas, France; Cgj, Crassostrea gigas, Japan; $\mathrm{CgCa}$, hybrid resulting from the cross between Crassostrea gigas, France and Crassostrea angulata, Spain; Cat, Crassostrea angulata, Taiwan.

\begin{tabular}{lcccc}
\hline Oyster populations & Geographical origin & Strain & $\begin{array}{c}\text { Total weight (mean } \pm \text { SD) } \\
(\mathrm{mg})\end{array}$ & Dry meat (mean \pm SD) $(\mathrm{mg})$ \\
\hline Crassostrea gigas & Marennes-Oléron, France & $\mathrm{Cgf}$ & $392.8 \pm 76.8$ & $14.5 \pm 3.4$ \\
$\begin{array}{l}\text { Crassostrea gigas } \\
\text { Hybrid Crassostrea gigas } \times \\
\text { Crassostrea angulata }\end{array}$ & $\begin{array}{c}\text { Hiroshima, Japan } \\
\text { Crassostrea gigas, Marennes- } \\
\text { Oléron, France } \\
\text { Crassostrea angulata, Cadiz, }\end{array}$ & $\mathrm{Cgj}$ & $261.2 \pm 88.9$ & $12.9 \pm 4.5$ \\
Crassostrea angulata & Spain & $349.2 \pm 40.9$ & $13.6 \pm 2.1$ \\
\hline
\end{tabular}

SD: Standard deviation.

\section{MATERIALS AND METHODS}

\subsection{Geographical strains}

Parental oyster samples were obtained from Marennes-Oléron (France) (Cgf), Hiroshima (Japan) (Cgj), Tunkang (Taiwan) (Cat) and Cadix (Spain) (Ca) (table $I$ ) and held in quarantine in similar environmental conditions at the Ifremer research hatchery. Each oyster population was characterized by both their geographical origin and mitochondrial DNA markers as previously described $[6,7,36]$. These recent studies showed that Crassostrea angulata, considered by most authors as a subspecies of Crassostrea gigas [34], can be clearly distinguished from Crassostrea gigas using mitochondrial DNA markers and that it originates from Taiwan. Although all the tested strains must be considered as Crassostrea gigas, the oysters originating from Tunkang (Taiwan) and Cadix (Spain) are named 'Crassostrea angulata' rather than 'Crassostrea gigas ssp. angulata' as this name is in common use in aquaculture $[6,15,25,36]$. Breeding was achieved by mass spawning of 100 oysters (strains, $\mathrm{Cgj}$ and $\mathrm{Cat}$ ) or by stripping of the gametes of mature oysters (Cgf: 21 females $\times 10$ males, hybrid strain $\mathrm{CgCa}: 21$ females $\mathrm{Cg} \times 15$ males $\mathrm{Ca}$ ). Larval rearing, settlement and spat rearing were performed according to usual hatchery methods. Five-month-old spat of each strain were then randomly sampled for oxygen consumption measurements.

\subsection{Respiration rates}

Respiration rates were determined by using a volumetric micro-respirometer [41]. The measurements were carried out individually on 12 oysters per strain using a system of micro-chambers connected to capillaries and kept under constant pressure (figure I). One oyster was placed per micro-chamber filled with seawater where a $\mathrm{KOH}$ solution was settled as a suspending drop. The latter maintained a constant $\mathrm{CO}_{2}$ concentration inside the micro-chamber, so that changes in gas volume were caused only by oxygen consumption. One micro-chamber with no oyster was used simultaneously as a control functioning similarly to a thermal barometer. All measurements were made at $20^{\circ} \mathrm{C} \pm 0.1^{\circ} \mathrm{C}$ using an ultra thermostat to maintain constant seawater temperature. We chose to examine the oxygen consumption at quite a high temperature $\left(20^{\circ} \mathrm{C}\right)$ to maximize metabolism, and therefore accentuate the difference in maintenance efficiency $[9,29]$. Respiration rates were measured every 2 min over a 40 min experimental time, leading to 20 values per oyster. Following the measurements, oysters were shucked and the wet meat frozen for $24 \mathrm{~h}$. Then, individual dry meat weight was obtained by freeze drying for $36 \mathrm{~h}$, and weighing using a $1 / 100 \mathrm{mg}$ precise scale. Experiments were conducted with Crassostrea gigas of $5.4-24.7 \mathrm{mg}$ dry meat weight.

\subsection{Data analysis}

To take into account allometric differences, which were mainly due to growth variability among oyster batches, respiration rate was calculated per unit dry meat weight $(\mathrm{mg})$ using the formula $[3,4]$ :

$$
R_{s}=\left(W_{s} / W_{e}\right)^{b} \times R_{e}
$$

where $R_{s}$ is the respiration rate of the standard animal in $\left(\mathrm{L} \mathrm{O}_{2} \cdot \mathrm{h}^{-1}, W_{s}\right.$ is the weight of the standard animal $(1 \mathrm{mg}), W_{e}$ is the measured dry meat weight of the animal, $b$ is the allometric coefficient and $R_{e}$ is the uncorrected respiration rate in $\left(\mathrm{LO}_{2} \cdot \mathrm{h}^{-1}\right.$.ind ${ }^{-1}$. The allometric coefficient of 0.77 was used for all batches [16] rather than 0.8 , obtained previously [9] on a larger oyster size range.

All the statistical treatments, including normality tests, ANOVA and tests were performed using the software Statgraphics ${ }^{\odot}$ V. The data were analysed using the following model:

$$
Y_{i j k}=\mu+s_{i}+i_{j / i}+e_{i j}
$$

where $Y_{i j}$ is the measurement of the $k$ th individual of the $i$ th strain, $\mu$ is the overall mean, $s_{i}$ is the population effect, $i_{j / i}$ is the individual within the strain effect and $e_{i j}$ is the residual. 


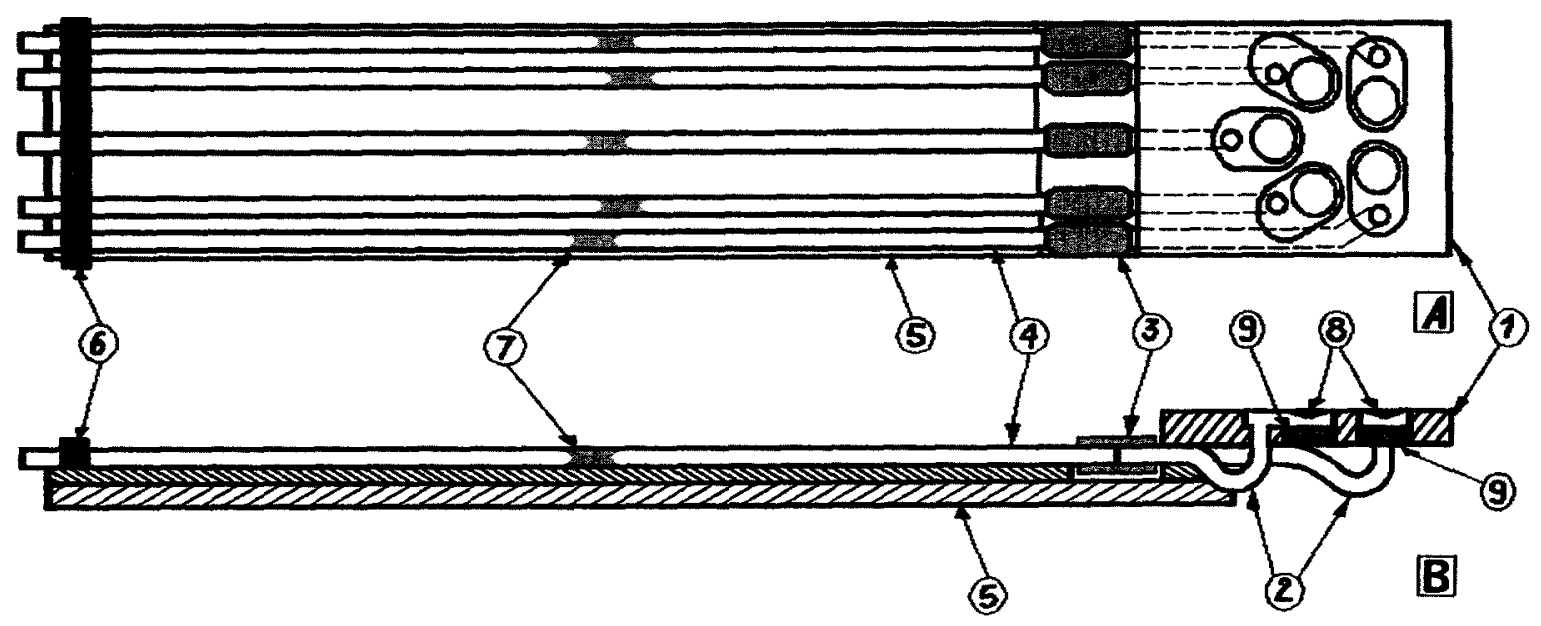

Figure 1. Micro-respirometer chamber system: A: view from above; B: cross-section; 1: brass plate with five micro-chambers, 2: capillaries, 3: plastic tubes, 4: measurement capillaries, 5: mounting base, 6: comb, 7: small column of coloured kerosene, 8: solution of KOH as a suspending drop, 9: oyster in small volume of seawater on the bottom of micro-chamber.

\section{RESULTS}

Characteristics of oyster strains are presented in table I. Average total weight ranged from $261 \mathrm{mg}$ $(\mathrm{Cgj})$ to $393 \mathrm{mg}(\mathrm{Cgf})$, while average dry meat weight varied from 13 to $18 \mathrm{mg}$ for the Japanese and Taiwanese strains, respectively.

Oxygen consumption rates of the different strains were compared using an ANOVA statistical test, and showed a significant origin effect (table II), (figure 2). More than $20 \%$ of the total variance was explained by this strain effect.

The French strain (Cgf) showed the highest mean respiration rate $\left(0.72\left(\mathrm{~L} \cdot \mathrm{h}^{-1}\right)\right.$, while the Japanese $(\mathrm{Cgj})$, Taiwanese (Cat) and the hybrid oysters $(\mathrm{CgCa})$ consumed $0.53,0.43$ and $0.41\left(\mathrm{~L} \cdot \mathrm{h}^{-1}\right.$, respectively $(\mathrm{ta}-$ ble III).

Based on their respective respiration rates, the four strains can be divided into two groups, incorportating $\mathrm{CgCa}-\mathrm{Cat}-\mathrm{Cgj}$ and $\mathrm{Cgj}-\mathrm{Cg}$ (table III). Pair comparisons of respiration rates by using the least square

Table II. Variance analysis (ANOVA) table for standardized respiration rates $\left(\mu \mathrm{L} \mathrm{O}_{2} \cdot \mathrm{h}^{-1}\right)$ of Crassostrea gigas strains.

\begin{tabular}{lccccc}
\hline Source & $\begin{array}{r}\text { Sum of } \\
\text { squares }\end{array}$ & $\begin{array}{c}\text { Degree of } \\
\text { freedom }\end{array}$ & $\begin{array}{c}\text { Mean } \\
\text { square }\end{array}$ & F-Ratio & P-Value \\
\hline $\begin{array}{l}\text { Between } \\
\text { strains }\end{array}$ & 0.69592 & 3 & 0.231972 & 3.49 & $0.0233^{* * *}$ \\
$\begin{array}{l}\text { Within } \\
\text { strains }\end{array}$ & 2.92259 & 44 & 0.066423 & & \\
$\begin{array}{l}\text { Total } \\
\text { (corr.) }\end{array}$ & 3.61851 & 47 & & & \\
\hline
\end{tabular}

* Statistically significant difference; ** highly significant; NS, not significant. method showed that only two pairs of means differed significantly, these were the strain Cgf versus the hybrid $\mathrm{CgCa}$, and the local $\mathrm{Cg}$ versus the Taiwanese strain Cat.

\section{DISCUSSION}

Based on our results, this preliminary study of oxygen consumption rates in juvenile oysters demonstrated that physiological variability exists among Crassostrea gigas strains and is probably related to geographical, physiological and/or genetic adaptations. The method appeared efficient for comparing oyster strains and detecting those characterized by low metabolic rates; it might, therefore, be of interest for aquaculture purposes. Moreover, the constraints concerning species transfers and introductions specified by the ICES Code of Practice [27] make a survey at such an early life stage of particular interest from a practical point of view. These constraints explain the limited number of physiological comparisons avail-

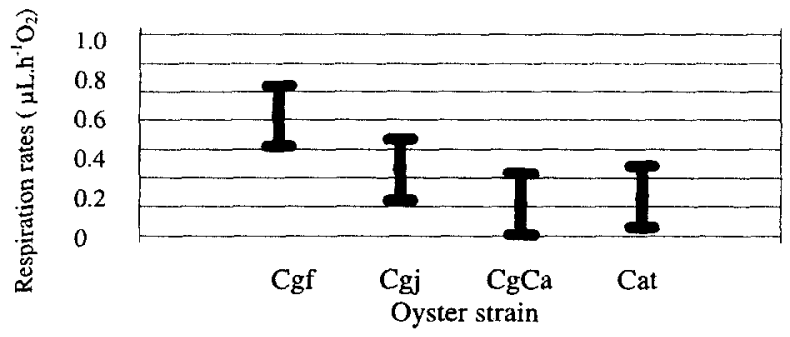

Figure 2. Comparison of the respiration rates for a standardized $1 \mathrm{mg}$ animal $\left(\mu \mathrm{L} \mathrm{O}_{2} \cdot \mathrm{h}^{-1}\right)$ between Crassostrea gigas strains (ANOVA results: means and $95 \%$ least square deviation intervals). 
Table III. Multiple range tests for standardized respiration rates of Crassostrea gigas strains using the least square deviation (LSD) method at $95 \%$, and statistically significant difference between means.

\begin{tabular}{|c|c|c|c|c|c|}
\hline \multirow{2}{*}{$\begin{array}{l}\text { Strains } \\
\mathrm{CgCa}\end{array}$} & \multirow{2}{*}{$\begin{array}{c}\text { Count } \\
12\end{array}$} & \multirow{2}{*}{$\begin{array}{c}\begin{array}{c}\text { Mean oxygen } \\
\text { consumption rates } \\
\left(\mu \mathrm{L} \mathrm{O}_{2} \cdot \mathrm{mg}^{-1} \text { dry }\right. \\
\left.\text { body weight }-\mathrm{h}^{-1}\right)\end{array} \\
0.40957\end{array}$} & \multicolumn{2}{|c|}{$\begin{array}{l}\text { Homogeneous } \\
\text { group }\end{array}$} & \\
\hline & & & $\mathrm{A}$ & & \\
\hline Cat & 12 & 0.43563 & A & & \\
\hline $\mathrm{Cgj}$ & 12 & 0.53008 & A & B & \\
\hline Cgf 12 & & 0.7165 & & B & \\
\hline \multicolumn{2}{|l|}{ Contrast } & & \multicolumn{2}{|c|}{ Difference } & $\begin{array}{c}+/- \\
\text { limits }\end{array}$ \\
\hline \multirow{2}{*}{\multicolumn{2}{|c|}{$\mathrm{Cgf}-\mathrm{CgCa}$}} & & \multirow{2}{*}{\multicolumn{2}{|c|}{$\begin{array}{l}* 0.3069 \\
* 02809\end{array}$}} & 0.21205 \\
\hline Cgf-Cgat & & & & & 0.21205 \\
\hline
\end{tabular}

able in the literature in contrast to genetic studies $[2,6$, $7,11,12,35]$.

Although not statistically significant, the Hiroshima strain showed an intermediary position in terms of cost of maintenance between the French Crassostrea gigas strain and both Taiwanese and Crassostrea gigas-C. angulata hybrid strains. This trend could be related to the discrepancies reported among Japanese strains [28, 31]. The low cost maintenance observed with the hybrid $C$. gigas-angulata and the Taiwanese strain tends to support the similarity between Taiwanese and European C. angulata populations, both from a genetical and physiological point of view [6]. However, the various costs of maintenance may induce overall growth differences between these strains and the European Crassostrea gigas as already suggested with Crassostrea virginica [30]. Meanwhile, decreased growth has been reported for hybrids, 8 and $49 \%$ for C. gigas-angulata and C. angulata-gigas, respectively [8]. Although lacking a complete scope for growth assessment, a growth difference between the European Crassostrea gigas strain and Crassostrea angulata was found to be correlated with a greater assimilation rate (by a factor of 1.7) for Crassostrea gigas [23]. Similar oxygen consumption rates and various feeding activities were reported to explain growth differences between hybrid and inbred Crassostrea gigas oysters [5]. Therefore, it appears critical to further evaluate growth potential and explain the relationships with physiological measurements by a comprehensive scope for growth assessment. Meanwhile, new assessments should be carried out over the annual temperature range to improve comparisons. Crassostrea gigas physiological activity has been measured over a wide range of temperature [9], and it was demonstrated that Crassostrea angulata has a reduced filtration activity below $10^{\circ} \mathrm{C}$, in contrast to Crassostrea gigas which was still active at $5{ }^{\circ} \mathrm{C}$ [26].

For a similar growth potential or scope for growth (SFG), the environmental impact of a species might be significantly different depending on whether energy is allocated mainly to maintenance or to production. In the case of the overstocked Marennes-Oléron bay, an optimal management strategy would be to culture a genetic strain which maximizes the use of energy input by the association of high assimilation rate, limited food retention and low energy maintenance cost. The Crassostrea gigas strain currently used in European waters showed the highest energy maintenance cost in this study, which might result in lower yields, increased mortality rates and higher pressure on the carrying capacity.

\section{Acknowledgements}

This work was carried out within the co-operation programme developed between Ifremer (France) and the University of Gdansk (Poland). We would like to thank J.H. Cheng, N.H. Chao and S. Akashige for providing the Taiwanese and Japanese parental oyster samples. We are grateful to M. Nourry, S. Heurtebise, C. Ledu and P. Phélipot for technical assistance in the hatchery and nursery. We thank H.R. McCombie for helping with the translation of this manuscript. This study was partly supported by the Conseil Général of Charente Maritime.

\section{REFERENCES}

[1] Bailly D., Aspects économiques et sociaux de la gestion des bassins conchylicoles : le cas de Marennes-Oléron, ICES Mar. Sci. Symp. 192 (1991) 234-241.

[2] Barber B., Impacts of bivalve introductions on marine ecosystems: a review, Bull. Natl. Res. Inst. Aquac. 3 (Suppl.) (1996) 141-153.
[3] Bayne B.L., Newell R.C., Physiological energetics of marine molluscs, in: Wilbur K.M., Saleuddin S.M. (Eds.), The Mollusca, Academic Press, London, UK, 1983, pp. 407-515.

[4] Bayne B.L., Hawkins A.J.S., Navarro E., Feeding and digestion by the mussel Mytilus edulis L. (Bivalvia: Mollusca) in mixtures of silt and algal cells at low concentrations, J. Exp. Mar. Biol. Ecol. 111 (1987) $1-22$. 
[5] Bayne B.L., Hedgecock D., McGoldrick D., Rees R., Feeding behaviour and metabolic efficiency contribute to growth heterosis in Pacific oysters Crassostrea gigas (Thunberg), J. Exp. Mar. Biol. Ecol. 233 (1999) 115-130.

[6] Boudry P., Heurtebise S., Collet B., Cornette F., Gérard A., Differentiation between populations of the Portuguese Crassostrea angulata (Lamark) and the Pacific oyster Crassostrea gigas (Thunberg), revealed by mtDNA RFLP analysis, J. Exp. Mar. Biol. Ecol. 226 (1998) 279-291.

[7] Boudry P., Barré M., Gérard A., Genetic improvement and selection in shellfish: a review based on oyster research and production?, in: Proc. Genetics and breeding of Mediterranean aquaculture species, Network on technology of aquaculture in the Mediterranean (TECAM), Zaragossa, Spain, CIHEAM and FAO editions, 1998, pp. 61-75.

[8] Bougrier S., Raguenes G., Bachère E., Tigé G., Grizel H., Essai de réimplantation de Crassostrea angulata en France, Résistance au chambrage et comportement des hybrides Crassostrea angulata-Crassostrea gigas, ICES, C.M.F:38, 1986, 10 p.

[9] Bougrier S., Geairon P., Deslous-Paoli J.M., Bacher C., Jonquières G., Allometric relationships and effects of temperature on clearance and oxygen consumption rates of Crassostrea gigas (Thunberg), Aquaculture 134 (1995) 143-154.

[10] Bougrier S., Collet B., Geairon P., Geffard O., Héral M., Deslous-Paoli J.M., Respiratory time activity of the Japanese oyster Crassostrea gigas (Thunberg), J. Exp. Mar. Biol. Ecol. 219 (1998) 205-216.

[11] Buroker N.E., Hershberger W.K., Chew K.K., Population genetics of the family Ostreidae, I. Intraspecific studies of Crassostrea gigas and Saccostrea commercialis, Mar. Biol. 54 (1979) 157-169.

[12] Calvo G.W., Luckenbach M.W., Non Native Oysters Survive and Grow in Virginia: Evaluating the Performance of Crassostrea gigas against Crassostrea virginica, in Relation to Salinity, in Chesapeake Bay and Atlantic coast waters, World Aquaculture Society, Las Vegas, 1998, 94 p.

[13] Collet B., Bases génétiques des caractères physiologiques impliqués dans la croissance chez l'huître creuse Crassostrea gigas, thèse dr., Institut National Agronomique Paris-Grignon, 1998, 208 p.

[14] Comps M., Bonami J.R., Vago C., Campillo A., Une virose de l'huître portugaise Crassostrea angulata Lmk, C. R. Acad. Sci., Paris, Sciences de la Vie 282 (1976) 1991-1993.

[15] FAO., Fisheries circular, 815, FIDI/C815, Rev. 11, 1999, Rome, 203 p.

[16] Gerdes D., The Pacific oyster Crassostrea gigas, Part II. Oxygen consumption of larvae and adults, Aquaculture 31 (1983) 221-231.

[17] Goulletquer P., Shellfish culture in France: Present status and new approaches to optimise production, in: Proc. 29th Annual shellfish conference, Shellfish Assoc. Great Britain, London, 1998, pp. 69-80.

[18] Goulletquer P., Héral M., History, present conditions and future of the molluscan fisheries of North America and Europe, Marine molluscan production trends in France: from fisheries to aquaculture, Mar. Fish. Rev., NOAA, technical report NMFS no. 129, 1996, pp.137167.

[19] Goulletquer P., Soletchnik P., LeMoine O., Razet D., Geairon P., Faury N., Taillade S., Summer mortality of the Pacific cupped oyster Crassostrea gigas in the Bay of Marennes-Oléron (France), ICES Statutory meeting, $\mathrm{CM} / \mathrm{CC}: 14,1998,20 \mathrm{p}$.

[20] Grizel H., Héral M., Introduction into France of the Japanese oyster Crassostrea gigas, J. Cons. Int. Explor. Mer. 47 (1991) 399-403.

[21] Hawkins A.J.S., Bayne B.L., Physiological interrelations, and the regulation of production, in: Gossling $\mathrm{E}$. (Ed.), The Mussel Mytilus: Ecology, Physiology, Genetics and Culture, Elsevier, Amsterdam, 1992, pp. $171-222$

[22] Héral M., Evolution et état du cheptel ostréicole dans le bassin de Marennes Oléron : intérêt d'une régulation, Rapp. Ifremer DRV 86-06-Aq/Trem, 1986, $35 \mathrm{p}$.

[23] Héral M., L'ostréiculture française traditionnelle, in: Barnabé G. (Ed.), Aquaculture, Vol. 1, Tech. \& Doc., Lavoisier, Paris, 1989, pp. 347-397.

[24] Héral M., Approches de la capacité trophique des écosystèmes conchylicoles : synthèse bibliographique, ICES Mar. Sci. Symp. 192 (1991) 48-62.

[25] Héral M., Deslous-Paoli J.M., Oyster culture in European countries, in: Menzel W. (Ed.), Estuarine and Marine Bivalve Mollusk Culture, CRC Press, Boca Raton, 1991, pp. 153-190.

[26] His E., Premiers éléments de comparaison entre l'huître portugaise et l'huître japonaise, Science et Pêche, Bull. Inst. Pêches Marit. 219 (1972) 1-9.

[27] Int. Counc. Explor. Sea, ICES Code of practice on the introductions and transfers of marine organisms 1994/Code de conduite du CIEM pour les introductions et transferts d'organismes 1994, 1995, $12 \mathrm{p}$.

[28] Imai T., Numachi K., Oizumi J., Sato S., Studies on the mass mortality of the oyster in Matsushima bay: search for the cause of mass mortality and the possibility to prevent it by transplantation experiment, Bull. Tohoku Reg. Fish. Res. Lab., no. 25, 1965.

[29] Koehn R.K., Bayne B.L., Towards a physiological and genetic understanding of the energetics of the stress response, Biol. J. Linn. Soc. 37 (1989) 157-171.

[30] Koehn R.K., Shumway S.E., A genetic/physiological explanation for differential growth rate among individuals of the American oyster, Crassostrea virginica, Mar. Biol. Lett. 3 (1982) 35-42.

[31] Marteil L., La conchyliculture française, 2ème partie, Rev. Trav. Inst. Pêches marit. 40 (1976) 149-346.

[32] Marteil L., Barrau W., L'ostréiculture japonaise, Science et pêche, Bull. Inst. Pêches marit. 215 (1972) 20

[33] Maurin C., Le Dantec J., The culture of Crassostrea gigas in France, in: Mann R. (Ed.), Exotic species in mariculture, Symp. on exotic species in mariculture, Woods Hole Oceanogr. Inst., 1979, pp. 106-122.

Aquat. Living Resour. 12 (4) (1999) 
[34] Menzel R.N., Portuguese and Japanese oysters are the same species, J. Fish. Res. Board Can. 31 (1974) 453-456.

[35] Moraga D., Osada M., Lucas A., Nomura T., Génétique biochimique de populations de Crassostrea gigas en France (côte atlantique) et au Japon (Miyagi), Aquat. Living Resour. 2 (1989) 135-143.

[36] O’Foighil D., Gaffney P.M., Wilbur A.E., Hilbish T.J., Mitochondrial cytochrome oxydase I gene sequences support an Asian origin for the Portuguese oyster Crassostrea angulata, Mar. Biol. 131 (1998) 497-503.

[37] Prou J., Pouvreau S., Héral M., Renaud V., Estimation de la biomasse d'huîtres non cultivées dans le bassin de Marennes-Oléron, Rapp. Ifremer DRV 94.06 RA/La Tremblade, 1994, 27 p.

[38] Smaal A.C., Widdows J., The scope for growth of bivalves as an integrated response parameter in bio- logical monitoring, in: Kramer K.J.M. (Ed.), Biomonitoring of Coastal Waters and Estuaries, 1994, pp. 247-268.

[39] Soletchnik P., Faury N., Razet D., Goulletquer P., Hydrobiology of the Marennes-Oléron Bay, Seasonal indices and analysis of trends from 1978 to 1995 , Hydrobiologia 386 (1999) 131-146.

[40] Tremblay R., Myrand B., Sevigny J.M., Blier P., Guderley $H$., Bioenergetic and genetic parameters in relation to susceptibility of blue mussels, Mytilus edulis (L.) to summer mortality, J. Exp. Mar. Biol. Ecol. 221 (1998) 27-58.

[41] Zurzycki J., Starzecki W., Volumetric methods, in: Šesták Z., Latský J., Jarvis P.G. (Eds.), Plant Photosynthetic Production: Manual of Methods, Dr W. Junk N. V. Publ., The Hague, 1971, pp. 257-27. 